\title{
Incomprehensible Men and Invisible Mothers Gendered Visions of a Fascist Future in Sweden 1933-1939
}

\author{
Beatrice Sjöström \\ Phd student in history \\ Dept. of Historical, Philosophical and Religious Studies Umeå University \\ beatrice.sjostrom@historia.umu.se
}

\section{Doi:10.5901/mjss.2013.v4n9p195}

\begin{abstract}
In this paper, with point of departure in theories on generic fascism and critical gender history, I analyse gendered visions in fascist propaganda produced by the National Socialist Labour Party (NSLP), an interwar Swedish party. The presented results are part of my forthcoming thesis, aiming at investigating how the NSLP legitimated and made fascism intelligible in a Swedish context. Even if the party strived to depict a radically renewed future in its propaganda, it was also stuck in its own context. As a small party on the fringe of the public sphere, the NSLP had to situate itself and its political message in relation to central contemporary political issues, socioeconomic structures and cultural norms, in order to make its ideology comprehensible. Additionally, it was a constant balancing act for the party trying to juggle the creation of an appealing propaganda while at the same time maintaining the organizational unity and not abandon the ideological core. By looking at different aspects of power structures based on first and foremost gender, but also race, class and age, in the ideological visions and interpretations of political realities in fascist propaganda my research will contribute to an extended understanding of the relation between ideology and gender in general and the gendered ideological construct of Swedish fascism in particular.
\end{abstract}

\section{Introduction}

Interwar fascism has never attracted much interest from Swedish historians. Previous research has studied the organizational structure and development of central indigenous fascist movements, while the ideological content remains mainly unexamined (Lööw 1990, 2004 \& Berggren 2002b). In contrast there has been a great activity in historical research about almost every other thinkable phenomenon possible to put in relation to Nazi Germany during the interwar period (Amark 2011). Leading to a telling silence around the fascist parties in the post war historical narrative of Sweden. Research about any kind of party political expression sheds light on the surrounding political discourse as well as it extends the understanding of the cultural and intellectual climate of that particular period of time. The study of political parties positioned in the margin of the political space can thus be as informative as studies of established parties. The aim with my forthcoming thesis is to investigate how the National Socialist Labour Party (NSLP) active from 1933-1950, legitimated and made fascist ideology intelligible in a Swedish context. NSLP can be viewed as an important ideological voice in the political discourse because all other parties, in one way or another, continuously had to relate to the new fascist ideology especially in relation to the rise and success of the regimes in Italy and Germany.

The NSLP gathered around 10000 to 15000 members, mostly farmers, workers and merchants. The party had its greatest electoral peak in 1936 but did not get enough votes to gain seats in parliament. In local elections the party was more successful especially in greater cities, on the west coast and the northern parts of the country. Representations of identities and gendered symbols in propaganda are crucial in order to understand the prosperity of both mediation and reception of fascist ideology (Mosse 1996, 1999 \& Spackman 1996). In this paper, with point of departure in theories on generic fascism and critical gender history, different aspects of gendered power structures, in ideological visions and interpretations of political realities in the NSLP's party propaganda, are therefore analysed. Such a critical gender perspective has never before been applied in fascist studies in Sweden and is quite rare in an international context, at least in studies of fascist ideology in general (Passmore 2003). Most tentative it is discussed if the difficulties to gain a broader political support could partly be explained by how the idealized roles of men and women in a future fascist society were represented in the party propaganda. 


\section{Background}

Sweden was not an exception compared to other European countries that saw the mobilization of fascist movements in the early 1920's. Sven Olov Lindholm, the party leader of the NSLP, had for example been politically active since 1926. The fascist organizations did never succeed to gain broad political support while almost every conceivable ground for the growth of fascism were missing in the country.

The fact that Sweden had not been in any war since the Napoleonic era made the nationalism lack feelings of irredentism; instead the nationalism got an inward protectionist and a strong cross-class character. The Swedish nation state was stable because of the ethnically homogenous population and absence of religious tensions. Even if the fascists strived to underline the cleavage between urban-rural areas this rhetoric was not in line with Swedish reality where this opposition was never distinct. Also the most severe conflicts between the left-right axes in society were balanced in the early 1920's, and conditions for dialogue steadily increased. In addition to this historically dependent stability the great depression did not hit the Scandinavian countries as hard as other European countries and the negative economic trend was quite effectively reversed. The crisis led to an increased entrance to already established organizations and it was hard for fascists as well as for communists to radicalize the Swedish working-class. Already at the end of FWW Sweden had a fixed five-party system and the political climate was increasingly dominated by emphasis on the importance of consensus. In 1933 the clearly reformist Swedish Social Democrats, together with the Agrarian party reached a crisis agreement. This agreement got a strong symbolic value, and together with the rhetoric about 'the People's Home' the Social Democrats managed to convince the majority of Swedes that democracy could deal with contemporary challenges in a successful way. Even if Swedish fascists definitely took contemporary ideas to the extremes several of the major traits of this new ideology - as for example antisemitism, beliefs in race biology, anti-democratic and anti-communist views - could also be found in propaganda from the other parties. The political space for the up-coming fascist parties was thereby limited. (Lindström 1985 \& Berggren 2002b)

The electoral failure can also be explained by the splinter of Swedish fascism. There was never one larger movement that managed to gather all supporters, instead the organizations were unstable and always engaged in internal debates and conflicts. It has though been estimated that Swedish fascism had a larger support than the poll results suggests. During the interwar period the age limit for participation in general elections was 23 , and it is likely that many of the fascist party members and supporters could not vote at all. It was not always possible to vote for small parties in every constituency while they had to register representatives in order to participate. Most often these parties only registered in areas where they knew that the support was strong. Remaining archives reveal that the majority of all small Swedish fascist and ultranationalist organizations were very visible in the public debate, and that they did perceive each other as belonging to the same new political force. There were 30000 members all together in the largest national socialist parties in the middle of the 1930's. In addition the radical conservative party the SNF, former youth organization of the Conservative party, gathered around 40000 members at the same time. This can be compared to the British fascist party, the BUF, that in 1934 had 50000 members, with a difference in population between Sweden and great Britain of 6.5 million compared to 50 million. (Lööw 2004 \& Berggren 2002a)

The NSLP was the largest clear cut fascist party during the interwar period. It had several local organizations and also a special unit for women, a youth organization as well as a minor SA-unit and a trade union. All party activities and decision making were guided by the leader principle as the party organization was supposed to mirror a forth coming national socialist society. The demand of a very high level of political activity on the members may have contributed to a higher amount of deeply engaged members in the NSLP compared to the established parties. In political style the party adapted to the German example with party uniforms, hell-greeting and the swastika as party symbol. (Lööw 1990) During the interwar period, written propaganda was the main channel through which political parties could express their message. The studied source material contains of all preserved written propaganda produced by NSLP from shorter pamphlets to more extensive debate books, with a focus on three major publications: an ideological journal, a newspaper and a youth magazine. All propaganda was directed by the party leader and individual opinions or internal debates were not allowed.

\section{Fascism and gender}

What visions did Swedish fascists have? How did they express their ideological message? These questions, that paved way for this PhD project, were asked influenced by what is called 'the new consensus' in fascist studies. Since the 1950s there has been ongoing international debates on how to define the concept of fascism. Diversities have appeared 
because of different epistemological points of departure and because of dissimilar opinions about the explanatory value of theories on ideology in relation to the Nazi German regime. After the second world war Marxist theorists explained fascism as the most perverted end of a capitalist economy. This assertion has been internally criticized among Marxists and analyses on how to grasp the relationship between fascism and capitalism have evolved. Weberian theorists argued that the rise of fascism could be explained from a class-perspective, meaning that the ruling elites in different countries through fascism resisted socialism. Critique towards this stance is that fascism cannot simply be described as antimodern, while it propagated for revolutionary changes and a new order. The new consensus, foremost connected to the British historian Roger Griffin, emerged from the totalitarianism approach that arose as an anti-marxist effort to expose similarities between fascism and communism. In a variety of degrees totalitarian approaches appear non-critical in a self reflecting sense. Liberal democracy is often constructed as the binary opposite to fascist- and communist ideologies creating a political scale based on moral assumptions. (Passmore 2002) Griffin has tried to capture fascist ideology in a shorthand definition describing the fascist minimum as "a political ideology whose mythic core in its various permutations is a palingenetic form of populist ultra-nationalism" (Griffin, Loh \& Umland 2006, p. 41). He claims that this definition can be used in comparative fascist studies, for example in order to situate the German Nazi regime in a broader European context. The debate about the usefulness of this shorthand definition is intense and it has been criticized especially by German historians who finds the definition too broad to be useful. (Griffin, Loh \& Umland 2006) As Griffin focuses on the importance of studying fascist ideology as any other political ideology in its own right, his writings encouraged a more thorough investigation of the Swedish case.

Griffin's definition of fascism does not offer any analytical tools in order to study fascism from a critical feminist approach. In fact, international scholars debating how to define the core of fascist ideology has had little interest in gender issues, George Mosse being the most prominent exception (Mosse 1996, 1999). Also in recent research on contemporary populist movements this tendency is apparent (Norocel 2011). A consequence of this gender blindness is for example the often repeated phrase about how fascists did not only strive to create a new society, but also a new Man. Even if it refers to a new kind of human this articulation becomes a theoretical ambiguity. Fascist ideology during the interwar period always rested on the perceived need for a clear dichotomy between men and women and their positions in society. On the other hand, researchers interested in gender perspectives have first and foremost tended to study interwar fascism in relation to women. This is also apparent in Swedish research where the explicit or implicit aim has been to explain the world view of some 'female paradoxes', engaged in fascist organizations, who are described as exceptions from the perceived linear development of Swedish gender equality. (Jonsson 2008 \& Bokholm 2008). The British historian Kevin Passmore has encouraged a more open dialogue between scholars primarily interested in ideology and those interested in gender or women's history, meaning that it could lead to a vitalization of both approaches. (Passmore 2003)

The tendency to study gender as something closest connected to women and to write women's history as a parallel history beside the already fixed male narrative has been a general tendency in historical research (Scott 1999). Joan W. Scott argue that historical research should instead investigate how perceived differences between the sexes structures power relations in society in a variety of ways that leads to a diversity of consequences. Perceived differences between the sexes legitimize power structures also in areas that can not directly be linked to gender or sexuality: "politics constructs gender and gender constructs politics" (Scott, 1999, p. 46). This is articulated in her definition of gender: "The core of the definition rests on an integral connection between two propositions: gender is a constitutive element of social relationships based on perceived differences between the sexes, and gender is a primary way of signifying relationships of power" (Scott, 1999, p. 42). The definition is made more specific through four different aspects where gender can be studied. The first aspect regards culturally available symbols - what kind of representations are invoked, how, and in what contexts? The second aspect is normative concepts that limit the meaning of the culturally available symbols stating norms as truths and not something socially constructed. The third aspect deals with how gendered norms affect the political organization of social institutions, and the forth aspect regards the production of subjective identities in line with or in opposition to the norms. How these aspects are linked together in different contexts, and also how they are interrelated to other power structures as for example race and class, is something that Scott thinks needs to be analysed. (Scott 1999)

My investigation is structured into three thematic strands centered around categories that can be described as main characters of the fascist narrative: the elite, the people and the enemies. Each category has been investigated through approaches related to the four aspects that Joan W Scott points out as central elements in the construction of gender. Main questions that are asked are: What ideological visions can be discerned as the most central goals connected to the elite/the people/the enemies and how are the visions supposed to be made possible through political 
reforms? How are these visions and political reforms legitimated and made intelligible in relation to contemporary norms and other societal contexts? In what ways are the elite/the people/the enemies visualized through representations of different bodies and through pictures and symbols? The results are analysed and discussed in line with Scott's theory: In what ways does perceived sexual differences interact with social organization in the fascist ideology? How are gender power structures related to other differences like race, class and age? Can disruptions, changes or contradictions be discerned in the propagandistic constructions of gender?

\section{Gendered visions of a fascist future}

\subsection{The elite}

This theme takes its point of departure in the fascist leader principle and how it was explained and represented in different ways in the propaganda. In fascist interpretation of history the whole process of Enlightenment and the principle of equality for all people was perceived as something negative. Democracy did according to the NSLP lead to class struggles, political turmoil and a self-destructive individualism and was described as a foreign system not compatible to the needs of the Swedish people. One of the cornerstones in the NSLP ideology was the conviction about the necessity to abolish parliamentarism and create an organic meritocratic state led by a strong leader backed up by a powerful elite. The fascist state to come was going to be based on the priority of promoting the survival of the Nordic race, which was thought to have its finest expression in the Swedish people. The leader should represent a perfect embodiment of the Swedish race which was going to legitimate his superiority. Typical Swedish characteristics were self-discipline, courage, steadfastness, initiative and dedication, and through trust on the capacity of the leader the Swedish people would find fulfillment and experience true freedom. A government consisting of a variety of experts, representatives for the different corporate branches that organized both the political and economical system, was going to support the leader in the decision making process. Swedish parliament would remain, even if all political parties were dissolved, but only with advisory status. ${ }^{1}$

The NSLP understood the importance of founding the new political system in the Swedish context and in order to make this vision comprehensible, the party adopted different strategies. A mythical historical narrative was used to legitimate the new political system, and the leader principle was constantly explained by comparisons to the governance of heroic Swedish regents in the past. In that manner the national socialist political system could be described as a continuation of the Swedish political system before the enlightenment. The leader principle was also presented as a realization of former Swedish theories about the organic state, for example elaborated by the radical conservative professor of political science Rudolf Kjellén. Random references to at that time already out-dated results in Swedish race science were used to legitimate the characteristics used to describe the Swedish people and the leader. Texts about the political system were often accompanied by gendered metaphors and symbols that made the suggested reforms appear to be a way to reinstall something natural and reliable: a strong masculine leader guiding the people in contrast to the liberal democracy, compared to artificial make up on the beautiful face of mother Svea. ${ }^{2}$ Based on these assumptions the NSLP could use central political concepts as nationalism, socialism and freedom in a different manner than their contemporary meanings in the democratic discourse. Socialism was synonymous to the principle of 'public good before self interest', but true socialism could only appear in a racial homogeneous society. Therefore nationalism was dependent on a conception of the nation as something based on biology. Most central was the concept of freedom and the party even called itself "The Lindholm liberty movement". True freedom meant freedom from foreign influences that threatened the race, and a strong sense of belonging to a people community with a metaphysical meaning of more than just a sum of individuals. ${ }^{3}$

The NSLP had a conscious approach to self presentation in propaganda when trying to mediate how a future

\footnotetext{
1 Dahlberg. P. (1935). "Från partidemokrati till korporativ folkstat". Nationell Socialism nr 1-4, 7, 9. Göteborg; Dahlberg. P. (1938). "Vår regeringsform, demokratien och NSAP:s författningsprogram". Nationell Socialism $\mathrm{nr}$ 2. Stockholm; Henning. B. O. (1937). "Nationalsocialismens rötter i Sveriges historia". Nationell Socialism nr 1-3. Göteborg. Se also: Unknown author. (1938). Den svenska nationalsocialismens program. Göteborg.

2 Dahlberg. P. (1935). "Nationell Socialism", Nationell Socialism nr 1. Göteborg; Dahlberg. P. (1935). "Dagens fråga". Nationell Socialism nr 2. Göteborg. Se also: Unknown author. (1938). Den svenska nationalsocialismens program.

${ }^{3}$ See for example: Dahlberg. P. (1934). "Den nordiska ledartanken.", Den Svenske Nationalsocialisten nr 26. Göteborg.; Dahlberg. Per. "Fyra år NSAP", Den Svenske Nationalsocialisten nr 4. Göteborg; Unknown author. (1939)."Norrlandsting i regn". Den Svenske Folksocialisten nr 44. Stockholm. Pictures: Den Svenske Nationalsocialisten. Julnummer 1933.
} 
fascist Swedish society was going to be constructed. Representations of the party elite consisted of mainly three categories designated with different roles in the political activism as well as in the propaganda: the leader, the intellectual elite and the fighting soldier. The NSLP wanted both to be perceived as a new revolutionary and anti-intellectual irrational force but also as a movement with ability to become a state-bearing meritocratic organization with a competent elite, if mass mobilization ever was reached. Sven Olov Lindholm frequently appeared in the propaganda represented as an embodiment of the ideal leader regarding his appearance, his actions and his trait of character. Symbolic drawings of iconic male figures in the newspaper often showed great resemblance with photographs of the party leader. Lindholm was fronted as a classless, young, brave political activist who was ready to sacrifice everything for the fascist vision. Personal information about him was confined to brief references to his background as a sergeant. Lindholm represented an activist leadership and very important in this presentation were his actions connected to the formation of the party in 1933, which was used as a focal point in the historical narrative about the growth of Swedish national socialism that evolved in the propaganda. He was also described as a speaker who evoked strong feelings and several of his speeches, often containing quotes from famous Swedish poems, were published both in the newspaper and in the youth magazine. ${ }^{4}$

Elaborated ideological articles in the party propaganda were written by members of the so called POLKOM, 'Politiska centralkommissionen'. In POLKOM leading party members had different areas of responsibility and were assigned to produce information about the party ideology in relation to contemporary political issues. This organisation was a way of staging the function of the fascist expert government in line with the envisioned corporative system. These party members were for example economists, students in history or religion, doctors, lawyers et cetera. Compared to the representations of the party leader in the newspaper these men were represented in a more intellectual manner as highly specialized individuals. Their portraits were often published alongside a shorthand description of their educational and regional backgrounds. ${ }^{5}$ The propaganda function of these intellectuals were contrasted to the party militia, the SAtroops, being portrayed as a homogenous collective, consisting of working class youngsters. Their primary duty was to guard the distribution of propaganda and to protect the party members. Representations of the SA-troops had a focus on their bodies and uniforms. If the men ever were quoted in the newspaper, their utterances were very anti-intellectual statements as for example simple jokes or exaggerated comments on political enemies. Conflicts and disputes between these men and the political opponents from other political parties were often described, portraying the young men both as heroes in the fascist struggle and as victims of an oppressive democracy. During the second world war this position in the propaganda was transferred to the volunteers who entered the battles in Finland or joined the German army. As the NSLP repeatedly stated that the transformation from the existing political system to the fascist state could become violent these men can be seen as a transitive embodiment of the revolutionary aspect of the ideology. ${ }^{6}$

Besides these representations of what the NSLP perceived as the core elite units also the youth organization and the political activity of ordinary party members played significant roles in the propaganda, for example the activity in the youth organization visualized the general moral uprising that was supposed to be needed among the people. In descriptions of meetings and party activities there were for example a clear aim to show that the male members came from different social backgrounds united by the fascist ideology in a strong community. Female members were, when they occasionally occurred in the party newspaper, instead represented as classless and foremost also nameless women engaged in traditionally female activities as for example cooking and sewing for the sake of the party. ${ }^{7}$ One exception from this trend was the lawyer Hilma Hansegård who during a couple of years wrote ideological articles in the newspaper, and also functioned in her professional role defending the party leader in a trial..$^{8}$ There are no examples in the propaganda of some kind of specific female political activism, although another ideal among young members can be discerned in the youth magazine where girls were given a slightly more politically active and personal appearance. ${ }^{9}$

\footnotetext{
4 Different authors. (1937). "Vad vill Lindholm/NSAP", Den Svenske Nationalsocialismen nr 83-94.

${ }^{5}$ Different authors. (1937 \& 1938). SA-mannen nr 1 \& 1 . Stockholm.

6 Unknown author. (1933). "Årstinget". Den Svenske Nationalsocialisten nr 13. Göteborg; Unknown author. (1937). "NSAP och Lindholm äro ett" \&"Auditorium". Den Svenske Nationalsocialismen nr 38. Göteborg; Unknown author. (1939). "När tinget öppnade". Den Svenske Nationalsocialisten $\mathrm{nr} 38$. Stockholm.

${ }^{7}$ Hansegård. H. (1935). "Äktenskapets kris och nydaning". Nationell Socialism nr 2. Göteborg.

${ }^{8}$ Various authors. (1935). Stormfacklan nr 2, 8, 11. Göteborg.

${ }^{9}$ Hagman, O. (1938) "Jordbrukets ställning i folkhushållet". Nationell Socialism nr 1.Göteborg; Törnqvist, C.A.(1938) "Kapitalism och socialism", Nationell Socialism nr 6. Göteborg; Unknown author. Den svenska nationalsocialismens program. Göteborg.
} 


\subsection{The people}

In the second thematic strand the relations between 'reproduction' and 'production' are analysed because the most important reforms in order to create a Swedish people's community were according to the NSLP the need for an agricultural revolution, a higher priority on eugenic issues and a re-organization of the labour market. In propagandistic presentations of these reforms, representations of the Swedish people as a collective as well as divided in different categories become apparent. In addition, the view on the historical development of the inner character of the Swedish people and the Nordic race in different times and contexts is expressed. The fascist dual attitude to modernity and tradition can be scrutinized for example regarding the the private sphere as well as the overall industrial development and urbanization in Sweden at that time. It is also possible to study if the party was responsive to popular opinions at the time and if tactical compromises were made in the presentations of the ideological vision in order to gain increased electoral support. The NSLP thought that capitalism left the people in a moral and reproductive crisis and promoted a negative economical development. The solutions presented were supposed to increase reproduction in order to secure the survival of the Swedish race, and to create a sustainable economy. Several articles in the propaganda described how the bond between Swedish farmers and their soil had been broken by industrialization and urbanization, and how a modern lifestyle connected to larger cities was dangerous and immoral. Therefore, NSLP wanted to reinstall traditional cultural values that they thought permuted the Swedish countryside, regarding for example marriage, love, children, work and religion. Agriculture was proposed to become the driving force of the economy, eventually making Sweden self sufficient with minimal amounts of import and export. Elaborated calculations on how to make this possible - by splitting larger estates into family yards and by cultivation of not yet used areas - were presented. ${ }^{10}$

In propaganda the contemporary Swedish people in general and the farmers in particular were represented as in deep distress and misery in need of a revolutionary change. The farmer's body was for example visualized as fatigued, bent and slim. In contrast the historical Swedish people was represented in a very positive romanticized way as strong and energetic workers having a high moral standard as well as being politically conscious. Also the traditional role of the farmers wife with full responsibility for the private sphere and the upbringing of the children was represented as a position that promoted strength, health and the inner female racial spirit. This female subject was though not underlined much in propaganda neither in articles nor pictures. The female position in the public sphere as an expert on domestic issues was only briefly mentioned in some of the scarce texts that had a focus on women's place in society. There was only one picture, a portrait of a woman and her daughter, that made this ideal visible in the newspaper during the whole interwar period. ${ }^{11}$

In interwar Sweden there was a general concern about declining birth rates that was politicized in 1935 as "Befolkningsfrågan" by Alva och Gunnar Myrdal, forcing politicians from all parties into a debate on how eugenics and social reforms could solve the problem. The NSLP explained the overall problem as an increased amount of abortions, combined with a high birth rate among degenerated social- and ethnical groups. The party was convinced that the people in general and the upper classes in particular due to feminism and women's participation on the labour market did have to few children. The solution in a future fascist state was to give great influence to doctors with expertise in race science. These doctors were going to have the power to decide which women were allowed to give birth, as well as to promote the birth rate among women perceived as racially fit by not allowing abortions. Racially fit families were also going to receive increased economical support from the state. Reproduction was closely linked to production by underlining the importance of restraining female participation on the labour market - which was perceived as something negative for both men and women as well ad the whole nation. Women that had career ambitions and a full time work risked not to prioritize their duty as mothers. Female participation on the labour market was also described as one of the main reasons for the increased male unemployment and lowered wages, that made it impossible for male workers to become family

\footnotetext{
${ }^{10}$ Berglund. A. (1937). "Kvinnans uppgift i den nationalsocialistiska staten", Nationell Socialism nr 7-8, Göteborg; Bergman. R. (1936). "Svensk rasforskning", Nationell Socialism, nr 4; Walles. E. (1936). "Vid svenska folkets dödsläger?", Nationell Socialism nr 7-8. Göteborg; Walles. E. (1938). "Från emigrationen till födelsestrejken". Nationell Socialism nr 1. Göteborg. Pictures: A farmers family, "Barnen hungra!". Den Svenske Nationalsocialisten 1934:6; A mother and her child, "Moder och barn från Dalarna", Den Svenske Nationalsocialisten 1935:96.

${ }^{11}$ Berglund. А. (1935). "Nationalsocialismen och det socialmedicinska problemet", Nationell Socialism nr 4. Göteborg; Berglund. A. (1935). "Socialhygienens utveckling till rashygien", Nationell Socialism nr 6. Göteborg; Berglund, Å.(1935). "Nationalsocialismen och den sociala indikationen". Nationell Socialism nr 10. Göteborg; Gernandt. E. (1935). "Fosterfördrivningsproblemet och nationalsocialismen". Nationell Socialism, nr 9. Göteborg.
} 
providers. ${ }^{12}$

The NSLP wanted to organize Swedish labour market in corporations in a way that intertwined the political and economical structure of society, by for example a total state control over production. The relation between the workers and their managers was supposed to bee guided by the leader principle - trust, discipline and responsibility - and class conflicts would then be eradicated. A strict focus on the conditions for industrial production and the industrial worker was apparent in the propaganda, even though the party in its rhetoric repeatedly said that it wanted to appeal to all workers despite their educational- and social background. For example the party argued for reforms that would create a more healthy work environment for the industrial worker, by ensuring an increased influence as well as a share of the profits. The genuine Swedish contemporary man was therefore represented as a member of the working class. The corporative system was supposed to be an elitist meritocracy where skills and hard work would always be properly valued. These labour market reforms were supposed to be backed up by the construction of new suburban areas with small family houses. That would restore the centrality of the home and make it possible for a farmer who left the countryside to work in city industries a chance to preserve his inner dignity and racial qualities. For the male family earner in general and the industrial male worker in particular fascism was described as a liberating force. This liberation were often embodied in the propaganda - showing how an iconic male, sometimes given attributes of the industrial worker, literally breaks free. ${ }^{13}$ This male symbol can also be seen as a symbol of the future modern and strong Swedish people, much in line with the bodily representations of the party leader and the characterization of the historical Swedish people, in contrast to the contemporary poor farmers for example.

\subsection{The enemies}

This thematic strand deals with the NSAP's description of the contemporary state of Swedish society through a main focus on antisemitism and on representations of political enemies. In representations of what the NSLP perceived as negative structures it is possible to analyse if and how the intersection of gendered, racialised and classing structures reinforces the overall political message without the actual political question discussed having a direct link to gender-, race- or class. In previous Swedish research it is foremost representations of the Jew and the overall emphasis on antisemitism that have been studied, not how and why antisemitism was expressed in a certain way and which consequences that might have had.

The underlying motivation for all proposed reforms in the party program was to eradicate the Jewish influence on Swedish society. It was explicitly stated that all Jews who had immigrated to Sweden after 1900 would be expelled under fascist rule. The remaining Jewish population would be segregated from the Swedish race. A long term solution of the so called 'Jewish question' was according to the NSLP to organize an international transport of all Jews to a nation of their own - Madagascar being the proposed area. Despite these harsh proclamations the NSLP stated that they did not want to promote vulgar antisemitism. Their suggestions were simply explained as the best solution also for the Jews. Beside this political reform, antisemitic propaganda was expressed at a more structural level, functioning as an underlying general preconception. It is for example apparent when different societal developments are described as explanations for contemporary society and legitimation of the ideological visions. Jewish influence is presented in a more subtle way, which in some cases can even make this antisemitic expression hard to detect and in need of some sort of de-coding.14

The NSLP's antisemitism was reinforced by representations of racial and political enemies in the newspaper through fiction, satire, articles and photographs of public persons. These representations made the antisemitism and the societal critique more graspable as they visualized the degenerative direction Sweden was heading culturally, politically and economically according to NSLP. They also made the demarcation line between wanted and unwanted members of a new fascist state clear. Distortions of the ideal national socialist male body had a central symbolic meaning in the satire pictures both depicting Jews and other political enemies. These persons were depicted with a fat or old body and the Jews were always portrayed in the same stereotypical way. The representation of the 'Jewish face' was present in many other contexts at this time - showing how 'the eternal Jew' and the Jewish mentality lurked behind every negative tendency. Femininity in these satires was represented both as a general weakness of something positive worth to protect and as the worst kind of degenerated and threatening influence. The positive weakness was embodied for example in the

\footnotetext{
12 Törnqvist. C.A. (1935). "Kapitalism och socialism", Nationell Socialism, nr 6. Göteborg.; Törnqvist. C. A. (1936). "Vår inställning till fackföreningsrörelsen". Nationell Socialism nr 7-8. Göteborg. Pictures: Den Svenske Nationalsocialisten (1936) nr 3 \& 32.

${ }^{13}$ Unknown author. (1938). Den svenska nationalsocialismens program. Göteborg. Se also: Dahlberg. G. (1936). "Näringslivets historiska utveckling". Nationell Socialism nr 2-6. Göteborg.

${ }^{14}$ Se front page: Den Svenske nationalsocialisten 1937-1939.
} 
symbolic pictures of mother Svea as a young, blond and beautiful girl being caught up in different dangerous situations. Negative representations of the so called modern woman, were common both in text and pictures. Political male opponents and Jews were often depicted as old and ugly women or children, showing that also age beside gender played a significant role in the representations. ${ }^{15}$

Frequently ordinary portraits of famous Swedish Jews and politicians were published, photographs of men whose appearance were in line with the established middle class norm at that time. The effect of these representations is dual. On one hand Jewishness and other perceived negative structures as communism and conservatism or liberalism is represented as something normative in Sweden and so integrated on all levels in society that one has to be really attentive to detect it. The articles and photographs in the newspaper can therefore be viewed as some kind of information to the Swedish people on the degenerative state of public affairs. Several articles describe in detail how these persons in a suspicious way act 'behind the scenes' with international connections. On the other hand these portraits can work in the opposite direction and in some way take the edge of the critique. Negative articles about individual women who took place in the public debate - for example the journalist Else Kleen and the politician Alva Myrdal were frequently published.16 Representations of political enemies show more diversity and a greater variety over time compared to visualizations of ideals. This is due to the fact that these representations were more dependent on the day to day political issues and discussions. It is also usual in political propaganda to emphasize negative trends to support the importance of suggested political reforms; a tactic that was also explicitly expressed by leading party members responsible over propaganda.

\section{Concluding remarks}

This paper has focused on different aspects of gendered representations in ideological visions and interpretations of political realities in the NSLP's party propaganda. In this concluding part I discuss what collective identities and subject positions were made visual and available through the propaganda and what that tells about power structures in Swedish fascism.

It is clear that the visions of a new elite, the proposed political reforms aiming at abolish democracy and the legitimization and representation of the leader principle, was based on gendered assumptions. The political subject targeted as the ideal future citizen was a racially defined, masculine "new Swedish Man". The idealistic descriptions of the Nordic race, that leading members of the NSLP was supposed to represent, were filled with allusions to historical heroic men and traditional male characteristics. The NSLP in an elaborated way used the male body and representations of the male party members as projections for fascist ideology. When female members were made visible they did not represent a special kind of future fascist political ideal, instead they were represented just as ordinary women doing the party ground service. One exception was the girls engaged in the youth organization who can be described as slightly more subversive female representations in relation to contemporary norms. The investigation shows that the core of Swedish fascism took a total male dominance and male power in the political field for granted.

In previous research on gender constructions and fascism there has been discussions on whether the fascist view on women's place in society should be understood as misogynist or as an attempt to create a new kind of emancipation by promoting a higher valuation of the traditional female sphere. It has been argued that the fascist vision was not as much misogynist as it was racist and oppressive in general - only promoting equal treatment for people belonging to the dominant race and at the same time denying all people human rights by abolish liberal democracy. (Passmore 2003) The NSLP propaganda repeatedly assured that the party did not strive to diminish women by giving men and women different responsibilities. But the strict segregation between female and male areas in society did come along with a different value system that emphasized the priority of male rights. Even if both male and female citizens were going to lose their democratic rights the male collective would not be restrained in the same way as women.

The party believed that the 'modern woman' needed to be harshly constrained if the traditional gender order was going to be restored. The eugenic approach underlined the perceived need for increased control by male doctors over the female body in general to promote a life lived in harmony with the racial designation of female nature. The female space in society restricted foremost to the private sphere. Fascism as the NSLP presented it, if realized, would give way for a highly diversified male collective enabled by reforms both regarding the private and the public sphere beside a homogenous female collective, where oppressive power structures regarding gender and race would predominate the life

${ }^{15}$ See articles called: "'Svenska' judar", published in Den Svenske Nationalsocialisten 1935-1936.

${ }^{16}$ The historian Martin Duberman presents the conditions and struggles of USA working class for the last quarter of nineteenth century in a novel. See. Duberman, 2005. 
of every individual woman. The massive propaganda focus on representing 'the enemies' created an imbalance in the propaganda between visualizations of the ideals in comparison to the countertypes. For example this form of imbalance is apparent in representations of women and in the symbolic use of femininity. The propaganda repeatedly visualized female counter types and female victims without making the ideal woman - the strong motherly subject - visible, establishing the meaning of femininity as something foremost negative and weak.

A disruption in the antisemitic discourse, aiming at depicting Jews as the cause of all contemporary negative trends, was caused by the multiple use of ordinary portrait photographs of opponent politicians and Swedish Jews. The antisemitism in different texts was softened as the most usual visualization of men and masculinity mirrored what can be described as in line with a broad middle class masculine norm at that time. This was not the case in the satire images where Jews were depicted in a very stereotypical manner. But as these images did not actually differ that much compared to main trends in political satire at that time even the negative representations of Jews in some way gave the unordinary strong antisemitism quite an ordinary appearance. Because of the extremely narrow masculine ideal made visible in the propaganda it was more likely for men to find find identity mirrors in the depicted enemies than in the idealized male political subject.

Could the difficulties faced by the NSLP to gain a broad political support in general elections partly be explained by how the idealized roles of men and women in a future fascist society were represented in the party propaganda? Before trying to discuss that issue it must be underlined that it is a very difficult question to answer. Even if gendered representations is very important in propaganda, people vote for different parties dependent on a variety of things apart from their gender or sexuality. The answer is also dependent on what kind of gendered representations that evoked political engagement at that time, and on how other parties handled gendered representations in comparison to NSLP. That is something that unfortunately has not been extensively studied. Due to the fact that propaganda is not only about what is being said but also how it is said it is possible that the NSLP could have gained a larger support from women had the propaganda contained more representations of the ideal mother and a more politically active female subject. A very similar view on women could be expressed in many different ways. Compared for example to the radical right wing party the SNF, that gathered more members than the NSLP, there was a great difference in how gendered representations appeared in propaganda. In the SNF's propaganda female and male representations were more in line with contemporary political and public norms, and a larger amount of space in the party newspaper was preserved for pictures of women that represented femininity as something utterly positive. Much more frequently than in the NSLP's propaganda articles about female issues were published and more frequently did women write articles. Women and men did co-work to a larger extent than in the NSLP organization at both an ideological and political level which lead to a much more visible active female subject. (Sjöström 2003)

I would argue that it was probably not the misogynist assumptions and arguments that caused the electoral failure of the NSLP because the presented opinion on women in the propaganda was shared also by many non-fascist Swedes, both men and women. In order for the NSLP to create a more appealing propaganda for Swedish voters it is possible to think that a more elaborated visualization of fascist ideals would have been more successful. As NSLP did not manage to raise class related discussions in the public debate or to gain support for their racial and antisemitic stance, maybe it instead would have been possible to gain a larger support if the misogynist presumptions in propaganda had been more explicitly stated. Could a frequent use of representations showing both the diversity of male subjects and the motherly strong idealized female that the party wanted to promote have made fascism more intelligible for Swedish voters?

\section{References}

Berggren, L. (2002a). "Den svenska mellankrigsfascismen - ett ointressant marginalfenomen eller ett viktigt forskningsobjekt?". Historisk Tidskrift nr 3, pp. 427-444.

Berggren, L. (2002b). "Swedish Fascism - Why Bother?". Journal of Contemporary History Vol 37(3), pp. 395-417. London: Thousand Oaks.

Bokholm, S. (2008) I otakt med tiden: Om rösträttsmotstånd, antipacifism och nazism bland svenska kvinnor. Stockholm: Atlantis.

Den Svenske Nationalsocialisten 1933-1939.

Griffin, R., Loh, W. \& Umland, A. (2006). Fascism Past and present, West and East: An International Debate on Concepts and Cases in the Comparative Study of the Extreme Right. Stuttgart: ibidem-Verlag.

Jonsson, B. (2008). Blod och jord i trettiotalet. Kvinnorna och den antimoderna strömningen. Stockholm: Carlssons.

Lindström, U. (1985). Fascism in Scandinavia 1920-1940. Stockholm: Almqvist \& Wiksell International.

Lööw, H. (1990). Hakkorset och vasakärven: En studie av nationalsocialismen i Sverige 1924-1950. Göteborg: Historiska institutionen.

Lööw, H. (2004). Nazismen i Sverige 1924-1950: Pionjärerna, partierna, propagandan. Stockholm: Ordfront förlag. 
Mosse, G. L. (1996). The Image of Man: The Creation of Modern masculinity. Oxford: Oxford University Press.

Mosse, G. L. (1999). The Fascist revolution: Toward a General Theory of Fascism. New York: Howard Fertig.

Nationell Socialism 1935-1938.

Norocel, O. C. (2011). "Heteronormative Constructions of Romanianness: A Genealogy of Gendered metaphors in Romanian radicalRight Populism 2000-2009". Debatte: Journal of Contemporary Central and eastern Europe 19:1-2, pp. 453-470. London: Routledge.

Passmore, K. (2002). Fascism: A Very Short Introduction. Oxford: Oxford University Press.

Passmore, K. (2003). Women, Gender and Fascism in Europe 1919-45. Manchester: Manchester University Press.

SA-mannen 1937-1938.

Scott. J. W. (1999). Gender and the Politics of History. New York: Columbia University Press.

Sjöström, B. (2003). "Politiska paradoxer?", Unpublished essay. Umeå University.

Spackman. B. (1996). Fascist Virilities: Rhetoric, Ideology, and Social Fantasy in Italy. Minneapolis: University of Minnesota Press.

Stormfacklan 1934-1939.

Åmark. K. (2011). Att bo granne med ondskan: Sveriges förhållande till nazismen, Nazityskland och Förintelsen. Stockholm: Albert Bonniers förlag. 